\title{
Gender Entrepreneurship in a Rural Scenario: A Case Study of South West Midnapore, West Bengal
}

\author{
Tapati Dasgupta, Atanu K. Roy and R.N. Chattopadhyay
}

\author{
Rural Planning \& Management Unit, Department of Architecture and Regional Planning, \\ IIT Kharagpur, Kharagpur 721 302, West Bengal, India \\ Telephone: (03222) - 220460 / 283208 (O) / 277625 (R); Fax: (03222) - 255303 / 282700 \\ E-mail: tdg_iitkgp@yahoo.com \& rnc_iitkgp@yahoo.com
}

KEYWORDS Entrepreneurship; gender; participatory forest management; Sabai grass

\begin{abstract}
Women entrepreneurship is a much nurtured notion of today. Women, after long years of toil and torment have come out of their painful past and they are now standing in a situation when they can handle all hurdles in firm hands and they have even established themselves as women entrepreneurs in different corners of the Third World Countries. In the urban sector, of course, women are displaying their acumen in different spheres. But rural women in India are for centuries living in a world of seclusion and inhibition. The age-long superstitious slumber has turned rural Indian women sterile and inefficient. They have forgotten their traditional skills for lack of training, polishing and suitable financial back-up. That they can ever come to limelight and can have an exposure in entrepreneurship arena is still an enigma. It is a laborious task to sensitize the gender rural section and persuade them to take up such activities which would help them in their process of livelihood generation with the application of simple and low cost technology which would finally motivate them to be self reliant. This paper unfolds the tale of struggle and strife witnessed by the tribal women in a rural set-up of South West Midnapore, West Bengal to give a realistic tune to the role of women entrepreneurship in a stringent manner. The message that we get from this paper is that a micro experiment of rural entrepreneurship can be a macro experiment in the years ahead.
\end{abstract}

\section{INTRODUCTION}

Indian women for ages have been the victims of social subjugation. It was from the middle of $19^{\text {th }}$ century onwards that the slow process of woman enlightenment and woman empowerment began and mass scale social reforms for the betterment of the condition of woman also took place. But unfortunately, after 57 years of Independence, it has been found that rural Indian women are still deep down in the mires of poverty, hunger, illiteracy, superstition and inhibition. Modern scholars have tried to analyze different reasons for this degraded position of women in India. The persistence of hunger and abject poverty in India and other parts of the world are due in large measure to the subjugation, marginalization and disempowerment of women. Women suffer from poverty in greater numbers and to a greater degree than men. At the same time, it is women, who bear the primary responsibility for actions needed to end hunger. Their concern for education, nutrition, health, and family income are also to be taken into account. Looking through the lens of hunger and poverty, there are seven major areas of discrimination against women in India.
Malnutrition: India has exceptionally high rates of child malnutrition because tradition in India reveals that women eat last and least throughout their lives even when they are pregnant and lactating. Malnourished women give birth to malnourished children, perpetuating the cycle. Therefore, the physical condition of Indian women always bears a low profile.

Poor Health: Females receive less health care than males. Many women die in childbirth of easily preventable complications. Working conditions and environmental pollution further impair women's health.

Lack of Education: Families are far less likely to educate girls than boys and far more likely to pull them out of school either to help out at home or from fear of violence. Sonalde Desai in 'Gender Inequalities and Demographic Behaviour' says that parents' reluctance to educate daughters has its roots in the traditional situation of women in India. Parents have several incentives for not educating their daughters. The reasons he has shown are mainly non-reproductive outcome, unstable and insecure situation etc. (Desai, 1994).

Overwork: Women work longer hours and their work is more arduous than men's, yet their work is unrecognized. Men report that "women 
like children eat and do nothing". Technological progress in agriculture has had a negative impact on women. Every woman actually is a workingwoman, whether she works in the house or outside it. Many women work to earn money. Workingwomen must know that they have some basic rights which are given by the law. In most cases, rural women are paid minimum wages and they are paid not in cash but in kind. Mies (1993) observed that "whereas operations performed by men were those that entailed the use of machinery and draught animals, thereby using animal, hydraulic, mechanical or electrical energy, women almost always relied on manual labour, using their own energy."

Unskilled: Women's skills are always overlooked in the primary sector, namely, agriculture, animal rearing etc. Moreover, some of their beautiful inherent skills like stitching, embroidery, weaving, knitting etc. are completely ignored by society. Women folk are often deprived of displaying their appropriate skills or do not avail suitable opportunities for exposing their innovative talents because of lack of initiative on part of Government to impart proper vocational trainings for developing and polishing their skills.

Mistreatment: In recent years, there has been an alarming rise in atrocities against women in India, in terms of rapes, assaults and dowry related murders. Fear of violence suppresses the aspirations of all women. Female infanticide and infoeticide are additional forms of violence that reflect devaluing of women in Indian society.

Powerlessness: While women are guaranteed equality under the Indian Constitution, legal protection has little effect in the face of prevailing patriarchal traditions. Women lack confidence to decide whom they will marry and they are often married off at childhood age. Legal loopholes are used to deny women's inheritance rights.

India has a long history of activism for women's welfare and rights, which has increasingly focused on women's economic rights. Recently, a range of Government programmes have been launched to increase economic opportunity for women, although there appears to be no existing programme to address the cultural and traditional discrimination against women that leads to their pitiable conditions. Ramlingaswami (1996) states that however much a mother may love her children, it is all but impossible for her to provide high quality childcare if she herself is poor and oppressed, illiterate and uninformed, anaemic and unhealthy, has five or six children, lives in a slum or shanty, has neither clean water nor safe sanitation and if she is without the necessary support either from health services or from her society or from the father of her children. According to Shiva (1988), another eminent Scholar of Feminist Study, "The women who participate in and lead ecology movements in countries like India are not speaking merely as victims. Their voices are the voices of liberation and transformation". Sen (1998) points out that when he took up issues of women's welfare, he was accused in India of voicing 'foreign concerns'. "I was told Indian women do not think like that about equality. But I would like to argue that if they don't think like that they should be given a real opportunity to think like that". By and large, it can be said that women in India for the past centuries have been mistreated, illassessed, disrespected, underestimated and overlooked in the mainstream of life and living. The present article deals with the problems and prospects of self-employed women in India and a case study of rural entrepreneurship of authentic character has been cited to exemplify the situation, where women from rural background have already proved themselves as real partners of men in life and living.

\section{PROBLEMS AND PROSPECTS}

The twin problems of rural entrepreneurship in India are sensitization of women and enlistment of women in work-pattern. The major problem so far faced is to inculcate in them the aptitude and interest for learning and to instill in them the spirit of self-reliance. Ample facilities are there. Sporadic attempts are being made by many Institutions for imparting training under various schemes but again social constraints keep women away from these facilities both in urban and rural areas. Mobile Training Centers usually attract more women as sending women away from family for training is not liked by family members nor do women like to neglect family. Secondly, part-time training facilities, especially during afternoon will attract more women to acquire skills. To enable women to undertake skill training, certain facilities like stipends, loans etc. will give them a good incentive for taking up responsibilities of entrepreneurship.

Contents of training also pose a problem. Social attitudes decide that certain crafts or small 
industries are suitable for women, i.e. sewing, knitting, teaching, basket- making, weaving etc. while mechanical or electrical skills are beyond their capacity. At the most, they can tackle sewing or knitting machines. But the repairs and maintenance of these machines are never taught to them. The excuse given is that women do not have basic educational qualifications. But lack of formal education does not mean that they cannot learn skill. If an uneducated boy can learn mechanics, car repairs, machine repairs etc. an uneducated woman is also capable of the same if she is given the proper training and opportunity.

Finance is the key-stone to any prospective venture. It has to be made possible at right time and the right amount is to be disbursed. As majority of self-employed women come from poor and lower middle-class families, they cannot invest any capital. In fact, women generally do not have any property in their names. House or property is mostly in the names of male members of the family. Moreover, families never like to put in any money in ventures started by women, though they risk everything for the sons.

Illiteracy and social constraints and even 'Purdah (veil) system' in some places restrain women from going to banks. The bank transaction procedure is cumbersome for them to understand. Secondly, they cannot afford to waste time due to delay as they need the working capital generally on daily basis. So the only resort left to them is the money lender who charges exorbitant rate of interest like rupees two on rupees ten per day. Therefore, it is essential to provide them with working capital easily and near their place of work.

The biggest challenge posed, relates to processing of raw materials and marketing of finished goods. To market the products, women again have to be at the mercy of the middlemen, who gulp the big chunk of profit. Here, middlemen try to exploit self-employed women at both ends. They deny them discount in purchase of raw materials on one hand and on the other they try to extract maximum credit discount and commission of finished products from women especially because they are ignorant of marketing mechanism. If women decide to eliminate middlemen, in that case they themselves are harassed a lot. In these days of stiff competition, lot of money is required for advertisement. If the product happens to be a consumer good then it takes a lot of time to win people away from other products and make the particular product popular. And then there is the tendency to question the quality of the product produced by women, though many agree that women are more sincere in maintaining the quality of work and time-schedule. Therefore, some kind of planned marketing through orga-nized way needs to be evolved, i.e. sale of pro-ducts through haats, exhibitions etc.

In rural areas, where agriculture is a prominent activity, agro-based activities like food preservation, bakery, dairy, poultry, piggery, fishery, could be taken up by women. They are helping men all these days without getting any credit or money. In areas where technology has been introduced and where women have good work situation, it is found that women labourers have often been displaced by men. Threshing of grain was almost exclusively a female task and with the introduction of automatic grain threshers which are only operated by men, women have lost an important source of income. Combined harvesters leave virtually no residue. This means that this source of fodder is no longer available to women, which has a dramatic impact on women's workload. So too, as cattle-dung is being used as fertilizer, it is less available as fuel for cooking. According to Banandiker (1996), commercialization and the consequent focus on cash crops has led to a situation where food is lifted straight from the farm to the market The income accrued is controlled by men. Earlier, most of the produces were brought home and stored, and the women exchanged them for other commodities. Such a system vested more control and responsibility with the women.

That with very little training, women can develop extraordinary skill has been proved by the Aurangabad experiment, where women showed better grasp in areas where forests predominate. Forest preservation and looking after trees is better done by women. Collection, assortment and classification of medicinal plants too are done by women if they are given the opportunity. Weaving on power-loom can be also done by them i.e. in Eastern regions like Mizoram, Nagaland etc., where handlooms are given to girls at early age. In districts where industries are located sparsely, ancillary works can be done by women. But, traditional industrial activities should be re-exposed to women. Maintenance and repair of small machineries can be taught to women and they should be encouraged to undertake repairing of tractors and well- pumps. Industrial Training Institute (ITI) can train girls 
and encourage them to start on their own. TRYSEM also confines to the training of sewing and knitting. Other items of training should be also included. In case of girls, educational requirements should not be the criterion of receiving trainings.

\section{METHODOLOGICAL ISSUES INVOLVED}

A Case Study Related to South-West Midnapore of West Bengal: The above-mentioned problems and prospects of gender entrepreneurship has been given a real thought and has been attempted to be partially solved by the initiative of Indian Institute of Technology (IIT), Kharagpur. The Participatory Forest Management (PFM) Project of IIT Kharagpur, sponsored by the Ford Foundation has taken up the task of enterprise generation through organization of groups and individual units on one hand and tagging the beneficiaries with financial institutions and larger marketing on the other as pilot programme since 1993. IIT has taken up the initial training exercise for development of skills among the villagers who are the ultimate entrepreneurs. The programmes and researches conducted by the Project Unit provide solutions at the micro level. These micro level studies have been undertaken in Nayagram Block of South-West Midnapore and Bundwan, Manbazar Blocks of Purulia District, both of them being Below Poverty Level (BPL) Blocks and inhabited mostly by tribals like Lodha, Santhal, Bhumija etc. Both areas are densely forested and the forest-fringe people are mostly dependent on forest produces for satiating their hunger. But they are quite unaware of the utility of the Non Timber Forest Produces (NTFP). It was a massive task of the PFM Project Unit to sensitize the poverty-stricken rural mass towards usages of various NTFPs through which they could earn a better livelihood and even nurture the idea of craft entrepreneurship for sustainability of such a prospective programme. The PFM Project Unit has worked intensively for the development of appropriate technology and its transfer to the relevant areas. This is followed by improvement and upgradation of the technology and the institutionalization of the entire endeavour. Marketability of the products, participation of the beneficiaries and income generation for the users are also analyzed for sustainability and durability of the activities. The identified areas of activities and technological interventions in processing of NTFPs at Nayagram can be broadly classified as:

A. Sabai grass and rope based utility and decorative items manufacturing

B. Manufacture of Atari \& Bamboo based Items

C. Collection, Cultivation \& Processing of Edible Mushrooms

D. Sal Leaf Plate \& Bowl Moulding Machine using Biomass as Fuel

E Collection, Cultivation \& Processing of locally available Medicinal \& Aromatic Plants.

F. Bee Keeping

G. Making of Ornaments \& Decorative Items from various plant parts

H. Mulberry Host Culture

\section{POLICY IMPLICATIONS}

This paper intends to give its thrust on the first agenda and accordingly the entire procedure of entrepreneurship through this craft has been described and the stages of gender entrepreneurship in a rural scenario have been depicted.

Sabai grass (Eulaliopsis binata), locally known as Babui is grown in abundance in the districts of Midnapore, Bankura, Purulia, Singbhum (East), Mayurbhanj, Balasore etc. in Eastern India. Traditionally, the people of this region used to grow and sell grass for paper industry or convert grass into rope for increasing profit margin. Technological intervention was felt necessary for multiplying value addition and hence livelihood generation among the people associated with Sabai culture was taken up with a new zeal. PFM Project Team conducted a two-pronged intervention, the first being the design development, while the second is technology introduction in the form of treatment of grass against insect attack, softening, dyeing, deodourizing etc. for manufacturing quality products demanded in the external markets. Successful experiments have thus been made in making Chairs, Tables, Sofasets, Ottomans, Door-Mats, Table-Mats, Carpets, Hand-Bags, Shopping-Bags, Hats, Chappals, Fruit-Bowls, Flower-Baskets, Laundry-Boxes, Bottle-Holders and a host of other utility and interior decorative items which have not only intervened the national market but also targeted the export market. The success at this technological venture has been established with the multiplication of value addition that is in the range of five to ten times that of rope-making and 10 to 20 times that of grass-trading. It is a 
surprising fact that women in this region have shown extraordinary skill, aptitude and acumen in developing this craft and $90 \%$ of the artisans are women in Nayagram Block (Chattopadhyay, 1998).

Marketing and Enterprise Development are the two key follow-up actions for successful transfer of the developed technologies. Marketing is not merely buying and selling but a dynamic function that links the production sector with the consumption sector. In rural areas, an efficient inter-organization linkage system is very important for the physical distribution of products and services. Here, the process of marketing adds to it crucial dimensions because of two characteristic aspects namely (i) informal nature of transaction and (2) coordinated system of production and marketing. The formal concept of marketing had been absent in the operational areas of IIT, where transfer of technology has been attempted, since in such areas the traditional transaction system was evolved as a natural phenomenon of production, distribution and consumption. This was so, because the traditional artisans concentrated on the production of utility items and consumables, which have markets in the local region. The two types of transaction system in existence before transfer of technology were (i) transaction in open competitive rural markets or haats and (2) one-to-one exchange usually of a non-competitive nature. The coordinated system of production and marketing in the rural sector adds new variables to the process of transaction. In this system, all the components of resource management, production design and marketing are intrinsically linked with each other (Das et al., 1996).

In the case of Sabai based items, production has been carried out both at centralized places or at decentralized units, but the accumulation of products has to be done at a single unit or godown which is considered as the source point in the linkage system. Once the destination nodes are identified, intermediate nodes and channels have been attempted to be traced back. A Team of artisans and functionaries of PFM Project Unit has taken up the responsibility of disposal of goods from source point to destination node for highest possible value addition. Marketing channel of Sal leaves, Mushrooms, Medicinal Plants, Atari \& Bamboo have also been identified in a similar way.

Another important dimension in the process of production marketing is appropriate Enterprise Building as Self Help Groups (SHGs). The factors considered in starting production organization include the following norms like type of organization, the nature of proprietorship, the nature of investment and finally the capability in organization building etc. Building organizations with a number of artisans, growers, collectors or graders have been found to be very effective for management of some products in which collective and shared actions are necessary. Some such important Organizations are Kharikamathani, Baligeria, Kurmipathra, Jarighati, Palasia, Jugisole, Chandabila, Amjam etc. (for Sabai based items) which constitute an apex body called NTFP Developers' Consortium (Fig. 1). Other Organizations of NTFPs like Sal leaf, Mushroom, Atari \& Bamboo, Medicinal Plants etc. are also functioning in the study area. These Organizations are functioning as SHGs for collection, cultivation, processing and marketing of respective items backed by the functionaries of different Projects of IIT Kharagpur. Some of them are supported by financial assistance from agencies like Directorate of Cottage \& Small Scale Industries, Govt. of West Bengal, West Bengal Scheduled Castes \& Scheduled Tribes Development and Finance Corporation, Jhargram Development Board, Nayagram Panchayat Samiti etc. Bengal State Aid to Industries (BSAI) loan of Rs.10,000.00 to artisans selected has been proved to be very effective in giving a fillip to the woman entrepreneurs to become self-reliant. Every year, a team of 15 good artisans, of whom at least 12 are women, are selected by the Project Unit for accruing this loan. The Consortium which has been set up comprises of both artisan beneficiaries and Project staff for handling entire marketing affairs. This, however, calls for formalizing the func-tioning of the groups. Portfolios have been assigned and specific responsibilities and liabilities of each executive, like President, Secretary, Treasurer etc. have been decided besides opening accounts with the local branches of several nationalized banks in the area for better handling of the finances which they are transacting. Moreover, on behalf of the Consortium every year, the arti-sans are also attending Handicrafts EXPO (Kolkata), International Trade Fair (Delhi), Bishnupur Mela, Haldia Mela, Urvi Handicraft Exhibition (Hyderabad), Siliguri EXPO, District Level Craft Competition etc. conducted by Directorate of Cottage \& Small Scale Industries, 
Govt. of West Bengal. It is really a redeeming feature that Nayagram women are top-level winners every time in the district-level competition and in the EXPOs and MELAs, both men and women are exhibiting their best performances. Recently, PFM Project has developed contacts and made interaction with Tribal Cooperative Marketing Development Federation of India Ltd. (TRIFED), New Delhi for transaction of PFM products through Tribshop.

The PFM Unit is conducting 59 to 60 Training Programmes round the year based on NTFPs in order to increase the economic standard of the above mentioned BPL Blocks. In order to approach the people of Nayagram for joining these Training Programmes and to motivate them for their own economic uplift, surveys in all the Forest Protection Committees (FPCs) were done. It was really a difficult task to knock at every FPC and to enlist the co-operation of the grass-root mass, particularly those belonging to the fair sex. Initially, the women did not come out of their stereotyped inhibitions and ill-conceived notions so quickly. But slowly, they were convinced of the good purpose of the programme and gradually became conscious of the benefits they would be gaining out of it. This persuasion needed long perseverance on behalf of the women members of the PFM Team, who were instrumental in sensitizing the gender group in Nayagram. Awareness and realization have at last helped the women to come out in large numbers and join the

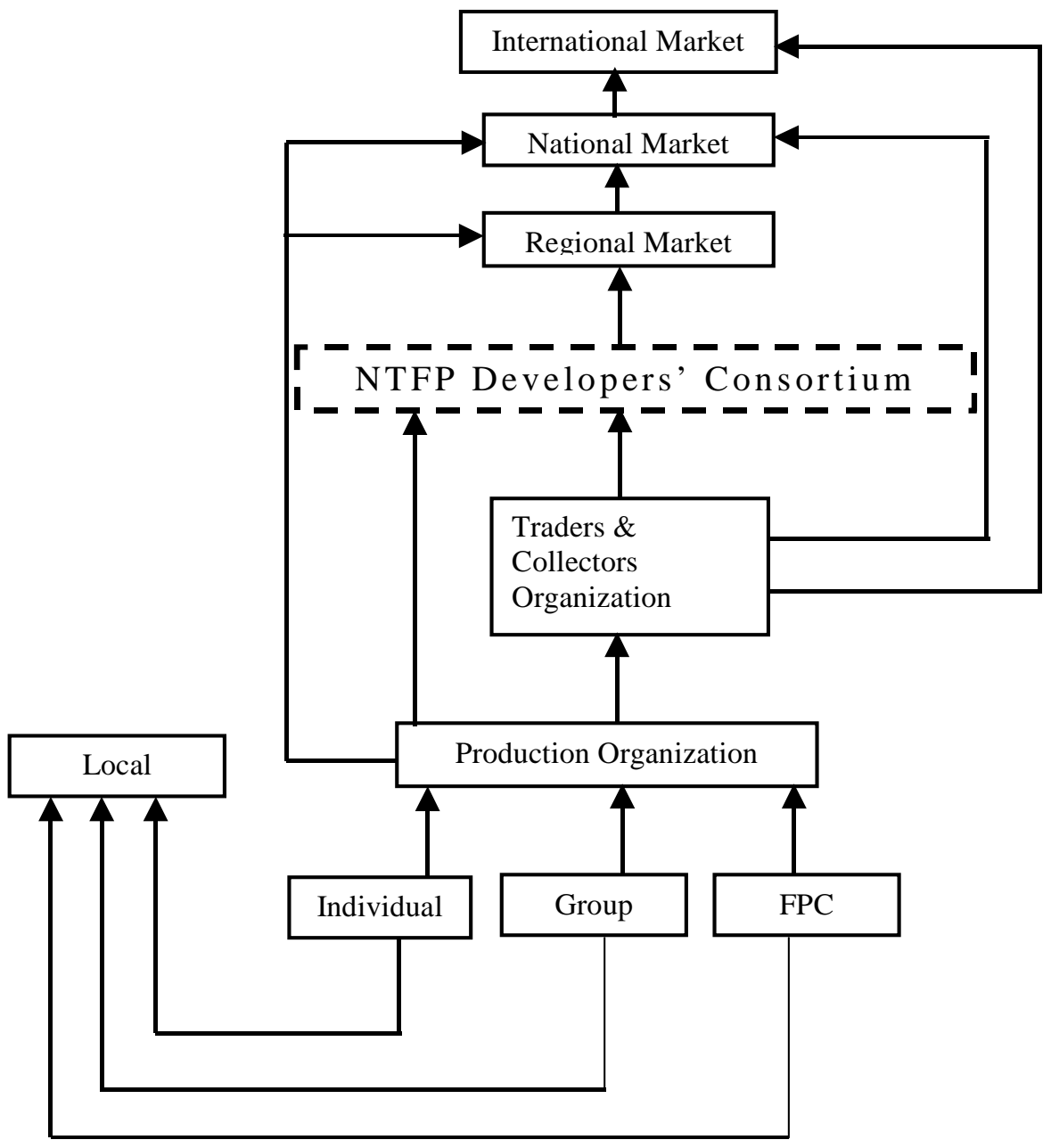

Fig. 1. Constitution of consortium 
trainings. Today, the overwhelming response of the female sex is really wonderous. More surprisingly, they are accepting all constraints at home to be present at the Training Centre at 10 A..M. and spending the whole day in learning the art of craft-making. Many of them are coming on cycle, sometimes they are accompanied by their husbands and brothers.

They keep their kids in charge of their grownup sons and daughters or sometimes in charge of in-laws. This enthusiasm in the field of Sabai craft has, of course, brought them in the limelight today in Nayagram. The ladies are now taking a pioneering role in giving the products the flair, the design and the variety. Even the illiterate ladies of tribal villages like Singdhui, a place which is ill-famous for criminal activities are coming forward to learn this art and to bring out a solution for healing their dire poverty. They are persuading their Lodha partners to take up this practice, even some are ready to give up their old practices of illegal felling, snatching, robbery etc. and are determined to accept this new path to augment their earning. Ms. Tilottoma Nayek, a young athlete, has taken up the responsibility to organize the programme of Sal Leaf Plate Making and Sabai Designing at Singdhui.

An analysis has been made after taking the interview of all the artisans who have taken Sabai training from the Kharikamathani Centre of Nayagram. Different types of questions were put to them in order to assess the extent of economic benefit that they are reaping out of this Sabai craft. They were also asked whether they were getting actual co-operation or not from the other members of the family, particularly from the male members. The note of self-reliance or selfconfidence could be discerned in the female voices of Nayagram equipped with the skill of Sabai training. (Dasgupta et al., 1996).

The money which they earn from marketing of Sabai products is quite a handsome amount (varying from Rs. 1200.00 to Rs. 5800.00 per order and per size of work). They spend this amount on various necessities of living including their basic requirements for production and marketing. The general picture of expenditure of an individual artisan is shown in a bar diagram (Fig. 2). This bar-diagram shows that the artisans at the first instance are more aware of the raw-materials of which they are in constant need. Of course, the PFM Project Unit provides them with some basic raw-materials, but the artisans are now in a position to repay the cost of raw-material at their earliest. Earlier, the ladies used to come to the Training Centre in shabby dresses and torn

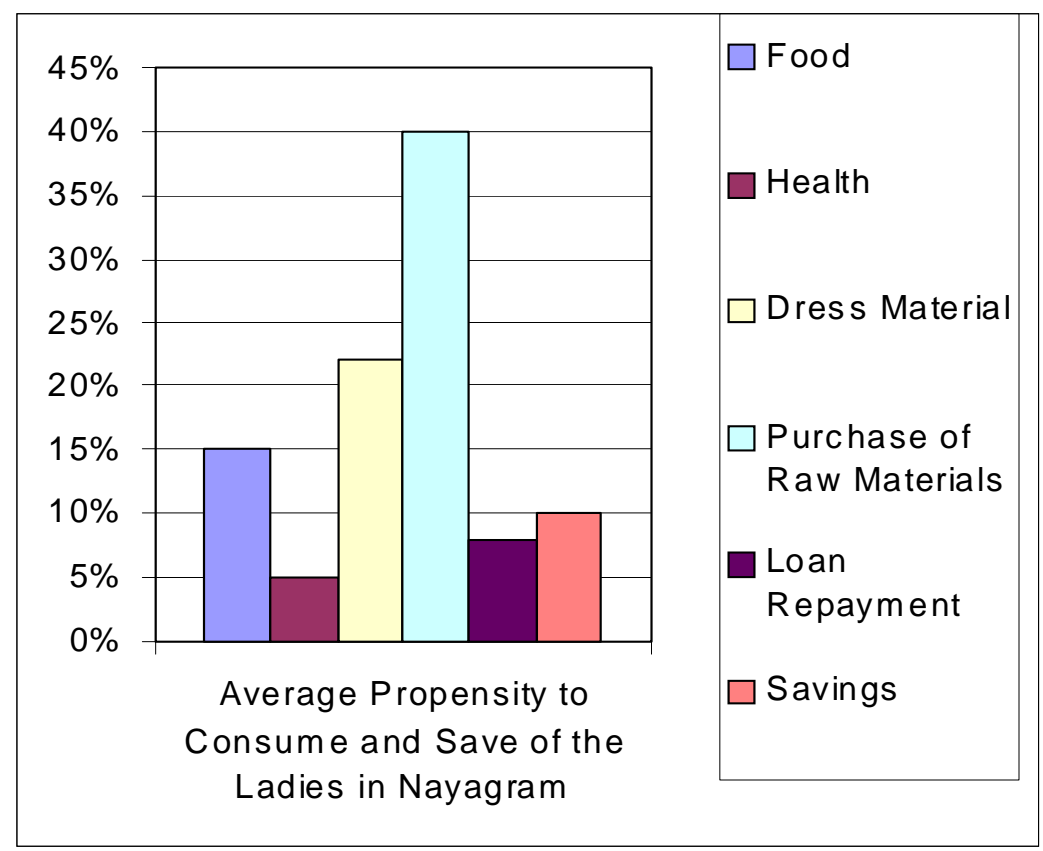

Fig. 2. Average propensity to consume and save of the ladeis in Nayagram 
chappals but now it is a pleasure to observe that the ladies can afford to spend at least $20 \%$ to $30 \%$ of their income on dress materials and they now present themselves in a more graceful manner. The woman artisans also can help their families in many ways regarding purchase of food stuff, medicines etc. and on education of youngsters of the family as the bar-diagram shows. Apart from this effort of maintaining the subsistence level of economy, they also try to save some money for future requirements.

The outcome of the above analysis, exemplifies the fact that the women in Nayagram are coming out of their veiled and secluded den marred in traditional slumber. They have learnt how to earn money with their own labour; have dreams of saving money for future and they have developed some conviction of giving financial support to their families. They are happy that they are not facing much hurdles from their families and their inconveniences are being shared and shouldered by the male members of the family. They believe that their capacity to earn is bound to rise and that would help them to think afresh for their family. The ladies in the Jugisole Unit alone can earn Rs. 4800.00 to Rs. 5700.00 each for a couple of export order in a month's time. The ladies have the faith that they would be able to teach the Sabai art to other family members as well as to their neighbours in the village. Some of them are already experimenting with the idea and others would not lag behind in the ensuing days.

That Sabai grass has brought about a miracle in the economic life of the people of Nayagram is now a gorgeous truth. The reality which has been deciphered has to be kept thriving in the present and in the coming years. This needs wholehearted participation from both ends- the trainers and the trainees and the vibrant urge for learning should also be kept stimulating. The passive attitude of the gender camp has been now moulded a lot and the venture towards gender entrepreneurship has taken a new dimension since last three years, which of course denotes a very promising feature in a rural scenario.

\section{CONCLUSION}

The above mentioned facts will help the readers to draw their attention towards a realistic truth of realizing the positive and negative features of entrepreneurship in a rural set-up The gender folk in India have gone through many vicissitudes of fortune and still they are crossing many disdains in order to acquire a firm position as far as financial stability is concerned. It is true that rural poverty, which is rooted deep down in its soil, cannot be annihilated so easily, but at least some rudimentary efforts have been initiated in this direction and the most encouraging feature is that the women have extended their tender yet tight hands towards building up of entrepreneurship in the rural sectors in a segregated but stable manner. The above- mentioned data of an empirical study in a micro area uncovers the fact that the rural women in this part of the country have started their work with a genuine mission and the concept of gender entrepreneurship is no longer a visionary idea. The micro experiment of today can be a macro study and a challenging task of the morrow. Women can be really empowered if they are entrusted with some real responsibilities and they themselves can do away with their own problems like mistreatment or powerlessness in their own way. Actual empowerment of women will be completed when they will be crowned with power, responsibility, skill and honour and rural Indian women, in spite of their many hindrances can win their own fortunes in a laborious but gracious manner.

\section{REFERENCES}

Banandiker, S. 1996. "Problems and Prospects of SelfEmployed Women", Paper presented in a Workshop 'Women's Involvement in Plan Process' at Institute of Applied Manpower Research, New Delhi.

Chattopadhyay, R. N. 1998. "Transfer of Technology for Rural Development - A stride towards Livelihood Generation in the Rural Sectors." Journal of Rural Development, 17 (3): Sp. Issue, July - September, Hyderabad: NIRD: 537 - 550 .

Das, C., D. Bhattacharya, T. Dasgupta, N. Das, S.C. Mahapatra, and R. N. Chattopadhyay. 1996. On the Aspects of Commercialization of Selected Non Timber Forest in the Nayagram Range of West Midnapore, West Bengal. Kharagpur: Indian Institute of Technology, (4) : $16-18$

Dasgupta, T., D. Bhattacharya, C. Das, N. Das, S. C Mahapatra and R. N. Chattopadhyay. 1996. Gender Portrayals in Forest Management of Nayagram. Participatory Forest Management Series, Kharagpur: Indian Institute of Technology, 7: 4 - 6

Desai, Sonalde. 1994. Gender Inequalities and Demographic Behaviour. New York: The Population Council

Mies, Maria. 1993. Ecofeminism. New Delhi: Kali for Women Press http://www.thp.org/reports/indiawom. htm.

Ramlingaswami, Vulimiri., Jonson, Urban., 1996. The Asian Enigma> Paris: UNICEF Organization. http:/ /www.thp.org/reports/indiawom.htm .

Sen, Amartya. 1998. October 26, "The Unheeded Conscience". New Delhi: 5

Shiva, Vandana. 1988. The Violence of Green Revolution. London: Zed Books. http://www.thp.org/reports/ indiawom.htm. 